\title{
Analyzing the Electoral Reform of the Chief Executive of Hong Kong: The Integration of Elite Democracy and Mass Democracy
}

\author{
Wen Chen \\ Shenzhen University, Shenzhen, China
}

\author{
Dinghuai Zhang \\ Shenzhen University, Shenzhen, China
}

\begin{abstract}
According to a decision of the National People's Congress (NPC) Standing Committee of the People's Republic of China in 2007, the 2017 Chief Executive election can be implemented by universal suffrage. It caused a lot of conflicts in the Hong Kong society. Nevertheless, on August 31, 2014, the NPC Standing Committee came to the decision that a 1200-member Nominating Committee should elect two or three candidates before a territory-wide ballot by ordinary voters and the 2016 legislative election would remain unchanged. This decision detonated Umbrella Movement afterwards. Hong Kong Pan-democratic camp, in conflict with the government, proposed “party nomination” or “civil nomination”. On June 18, 2015, the Legislative Council rejected this unmodified electoral reform proposal, which was uncommon under the "One Country, Two System”. Hong Kong, as the Special Administrative Region, enjoys high-level autonomy, yet it can be influenced by the intervention of the Central Government. Analyzing the decision-making and intention of the Central Government regarding the electoral reform of the Chief Executive of Hong Kong will facilitate our understanding of the political development of Hong Kong in the near future. This paper argues that the design of the electoral reform will be critically important for the political development in Hong Kong. On the one hand, the Central Government has to follow the Basic Law, for example, Article 45, which stipulates the election procedure. On the other, it emphasizes that the Chief Executive pledges loyalty to Beijing, and only specific design of the electoral reform can guarantee it. The practice of democratic principles exists with the election of freedom and justice. Worldwide experience demonstrates various democratic election mechanism and system, none of which can apply to all societies. Democratic election development Mainland China, Hong Kong Administration, and Macau Administration have difference in history. They should explore the democratic election mechanism, which takes root in and suits each cultural characteristics. As is well known, democracy relies on competition and compromise between conflicting principles and stakes. The election for the Chief Executive in Hong Kong of 2017 is a product of competition and compromise between different principles and stakes. This paper argues that the Chief Executive election of 2017 is a combination of elite democracy and mass democracy.
\end{abstract}

Keywords: electoral reform, mass democracy, elite democracy

\section{The Theory and Practice of Elite Democracy and Mass Democracy}

It has been a repeated debate that "who shall rule" ever since political thoughts came into being in human societies. Since the 20th Century, the answer to this question has become that "the people shall rule". Up to

Wen Chen, Associate Professor, Contemporary Chinese Politics Research Institute, Shenzhen University. Dinghuai Zhang, Professor, Contemporary Chinese Politics Research Institute, Shenzhen University. 
now, there has not been any political thoughts that win recognition and agreement as democracy. Politicians of every country declare their democratic belief and engage in the democratic projects that are justified by them. In this sense, democracy has become "a good thing” (Yu, January 5, 2007) and even "a life style”. Democracy discussed in this paper is a procedure and methodology in the political arena. As Joseph Schumpeter argued, democracy is an institutional arrangement for political decision and implementation, under which some one gains the power of decision-making through campaigning for votes (Schumpeter, 1999, pp. 395-396).

Democracy, originating from ancient Greek, demos (which is people) and kratos (which is power) means the power of people or the power belongs to the people. Modern democracy offers the rule of the majority, instead of letting everyone to rule or share equal political influence. Democracy in the etymology or in the idealism is different from the democracy in the reality. Giovanni Sartori pointed out: (1) the ideal of democracy cannot define democracy in the reality, and in turn, democracy in the reality is not same as the ideal of democracy, and these two can't be same; (2) democracy comes from the interaction between the idealism and pragmatism. Elite democracy comes into being as a political theory and practice from the stress on the pragmatic aspect of democracy.

Elitism categorizes the superior, the best, or the outstanding group of people. Generally speaking, elite defines the privileged minority with power, wealth, or authority, regardless of its rightness. The elite democracy theorists, represented by Weber, Schumpeter, and Sartori, criticized the substantive democracy centering on the rule of people and the public participation in decision-making, and argued for procedural democracy, centering on the governance by the elite and through competitive election.

Comparing elite democracy, mass democracy emerged later. In the English language, popular democracy and mass democracy are both used to describe it, meaning the ruling of the majority. Historically speaking, western democracies applied democracy among nobility. With industrial and capitalism development, democracy among capitalistic stakes replaced democracy among nobility. The rise of capitalism interests enlarged the working class, which demanded on sharing the power. The first step of mass democracy was that the working class gained votes. With the deepening of civil rights movements, women and minority groups participated in politics. Thereafter, western democracies veered the direction from elite democracy toward mass democracy.

From the perspectives of western political thoughts, not many research milestones have been achieved on the topic of mass democracy (Wei, 2008, p. 14). In contrast, elite democracy is the mainstream of modern democracy research, as it questions the rationale and feasibility of the rule of people. From the perspectives of democratic political thoughts, Schumpeter theorized the transformation from mass democracy to elite democracy. Democracy has transformed from the rule of people to the selection of governors by voters. The plural concept of people becomes the singular concept of voter. Democracy becomes the selection among competing elite groups by voters. The role of mass participation is limited to the election of government leaders every four or five years. As Samuel Huntington (1998) noted, the core procedure of democratic politics is that the ruled select the ruling through competing election (p. 4). Wang Shaoguang (2008) considered this transformation as two changes: the change from the people to the voters and the change from the governance by the people to the selection of the candidate, the goal of which is to defend the interests of the elite society (p. 45, 53). 


\section{Elite Democracy and Mass Democracy are Mutual Complementary}

In a large, modern and complex society, how to construct a democratic system is an issue confronted by any country or society aiming at democracy. On the one hand, it needs to satisfy the pursuit for egalitarianism, and on the other, it needs to avoid the conflict with the social order. To achieve balance in between, the difference and interaction between elite democracy and mass democracy provides a solution. John Mill stated that representativeness is the best combination between mass participation and elite governance, the perfect consistence between egalitarianism and efficiency, and the ideal polity. Although democracy is good, we should understand that mass democracy or unconfined democracy has its own flaws. The enlightenment, with a tint of anti-democracy, questioned the conventional wisdom of the mass public and also questioned the rule of the majority as not based on rationality. The irrationality of the mass public has been reflected from Milton to Voltaire (Stromberg, 2005, p. 275). Tocqueville (1997) believed that the tyranny of the majority would invade individual freedom and smothers creation (pp. 292-299). In Revolt of the Masses, Jose Ortega y Gasset warned that the arrival of the mass democracy would cause the collapse of civil society and moral order and pave the way for authoritarian to usurp power with the help of the mass public's raw instinct (Heywood, 2009, p. 256). In summary, it has been the mainstream to question and criticize the irrationality of the mass public, and it is the important practice of democracy in western nations to confine the mass participation in political affairs based on wealth, education, gender, and age, etc..

At the turn of 20th Century, men gained suffrage, and the western society entered into the mass democracy. In the political affairs, the loss of order, the lost image of democracy, and avoidance from freedom led political thinkers, such as Pareto, Mosca, Michels, Weber, and Schumpeter to reflect on the feasibility of mass democracy and construct elite democracy—which means all governance is done by the elite, the minority. According to elite democracy, the mass public cannot directly excise political authority in any situation. Even in democratic polity, the idea of rule by the people is a fairy tale, covering the governance of caucus, which controls representativeness (Miller, 2002, p. 238).

The suspicion has it reasons. In a large, complex society, the mass participation has difficulty and presents limitation to mass democracy. Hao Zhang elaborated his concerns: While the mass public would gradually lose their activity in political participation, the interest groups seize the opportunity to control the government and wield influence in policy-making for its own interest, regardless of the public interest. To certain extent, this is normal to democratic politics. Nevertheless, when it crosses the boundary it paralyzes democracy (Hao, 2006, p. 129). It becomes a difficult issue for political scientists that how to maintain proper political participation and not to cause participation overload or reduce the activity of public. In recent years, being challenged are the assumptions of the public choice theory that voters are rational, self-interest driven, and economic man. As an example is Bryan Caplan's book, The Myth of Rational Voter (Bryan, 2007). He argued that voters select policies based on their rooted mistaken understanding.

Nevertheless, elite democracy cannot negate mass democracy. The value of democracy has been widely recognized and spread. Nowadays, any excuse to oppose democracy would hardly win support in academia and media. Politics in a modern society is essentially politics of the public, and any modern society needs to figure out how to involve the mass public into its polity.

In summary, elite governance and mass democracy do not necessarily run against each other, yet they can act complementary to each other. Admission to the reality of elite democracy does not mean to ignore mass 
democracy because the elite class cannot gain legitimacy without votes. The mass public is ideal with inner contradictions and can't be implemented smoothly. Therefore, mass democracy and elite democracy are both indispensable. Neither of them can negate the other. In designing democratic election mechanism, it is possible to solve complicated problems arising at democratic transformation when mass democracy and elite democracy are allowed to be complementary to each other.

\section{The Nominating Committee Demonstrates Elite Democracy}

In a modern society, the best way for the elite governance to gain legitimacy is through democracy. Through democracy, the elite class obtains agreement from the mass public, which gives the legitimacy of governance. As a commercialized capitalist society, Hong Kong has four major industries: finance, logistics, tourism, and specialized services. Since the economic foundation determines superstructure, the economic foundation of Hong Kong determines that elite democracy is suitable to the Hong Kong society. According to the Basic Law of Hong Kong Article 45,

The Chief Executive of the Hong Kong Special Administrative Region shall be selected by election or through consultations held locally and be appointed by the Central People's Government.The method for selecting the Chief Executive shall be specified in the light of the actual situation in the Hong Kong Special Administrative Region and in accordance with the principle of gradual and orderly progress. The ultimate aim is the selection of the Chief Executive by universal suffrage upon nomination by a broadly representative Nominating Committee in accordance with democratic procedures.

Apparently, the Nominating Committee is a unique nomination mechanism, and possesses a very important position in the election of the Chief Executive of the Hong Kong Special Administration Region (SAR). It also demonstrates elite democracy in the process of democratization in Hong Kong.

First, the Nominating Committee mechanism is elite representativeness. The predecessor of the Nominating Committee is Election Committee, an organization formed out of election. Its important function is to elect the Chief Executive of the Hong Kong SAR. According to the amendment to the Basic Law, the election committee is composed of 800 people, equally divided among these four societies: (1) industry and commerce; (2) professional services; (3) social services, religion organizations; and (4) legislative representatives, Hong Kong representatives to the National People's Congress, and Hong Kong representatives to the Chinese People's Political Consultative Conference. The term is five years. The Election Committee began from 1998, demonstrating an institutional arrangement to empower Hong Kong people to elect their Chief Executive. It was designed to widely represent Hong Kong people to nominate candidates for Chief Executive. Essentially, it allowed the elite society of Hong Kong to elect a chief executive and was designed to achieve to universal suffrage gradually according to actual situation. In summary, the Nominating Committee is elite representativeness, with which the central government expects to reduce the uncertainty of universal suffrage.

Second, the Nominating Committee indicates the tolerance to every stakes in Hong Kong society and demonstrates balanced participation. On the one hand, Hong Kong is a commercialized city, where commerce and finance have contributed almost 90\% gross domestic production (GDP). The institutional design needs to take into important consideration the pursuits of capitalists in Hong Kong. On the other hand, Hong Kong is a cosmopolitan city with civil society. Its development replies on cooperation among all sectors of the society, including industry and commerce, professionals, and working class. Therefore, the election of the Chief 
Executive of Hong Kong SAR should take into consideration the stakes and interests of every sector of the society, allowing each sector to equally participate and reflecting the diversified political pursuits. Shi Gongqiang pointed out that the mechanism of Nominating Committee is political pluralism because it includes varying political influence. So the Nominating Committee is an institutional organization which exceeds party, geographic, and community divide. It plays the role of nomination within a party, while it surpasses partisanship and represents the varying sectors of Hong Kong society (Shi, 2014).

Third, the design of Nominating Committee is suitable for the economic development and capitalism in Hong Kong. The Basic Law of Hong Kong Article 5 stipulates that after 1997 the previous capitalistic system and way of life shall remain unchanged for 50 years. In other words, it implies that the design of political system in Hong Kong SAR should fit into the capitalism economy and long-term prosperity in Hong Kong and that the chief executive and his administration should play an important role in this process. To serve this purpose, the Nominating Committee becomes an indispensable part in the political mechanism of Hong Kong SAR, limiting the suffrage of the mass public to maintain capitalism and ensure the long-term political stability, economic development, and prosperity.

Fourth, the Nominating Committee is designed to ensure a patriotic chief executive and prevent those who are against the central government from succeeding in his campaign. According to the Basic Law of Hong Kong Article 43,

The Chief Executive of the Hong Kong Special Administrative Region shall be accountable to the Central People's Government and the Hong Kong Special Administrative Region in accordance with the provisions of this Law.

Thus, the patriotism of the chief executive becomes a requisite. Senior officials of mainland China, Qiao Xiaoyang, Director of Commission for Legal Affairs of the National People's Congress and Li Fei, Director of Committee for the Basic Law of the Hong Kong SAR made clear the position of the central government, respectively in March 2013 and November 2013. The central government would not accept an antagonistic chief executive in Hong Kong. The nominating procedure of Nominating Committee is institutional, so it must reflect the consensus of the Committee. This reflects the requirements of "One Country, Two System," and it is also determined by the legal status and role of the chief executive. The election mechanism for chief executive shall provide corresponding institutional function, and the Nominating Committee shall play this role.

At last, the Hong Kong society should initiate rational dialogue on the potential problems confronting the Nominating Committee in order to form consensus and realize universal suffrage. Some opine that the Nominating Committee is a transition arrangement, which reflects the pursuit that the businessmen should rule in Hong Kong. We argue that problems cannot be resolved by terminating the Nominating Committee, but by improving its institutional design of functional constituency. Although such design has some problems, it can be democratized through reform, which could become an effective institutional arrangement for the balance of power. In terms of improving the institutional design of functional constituency, it shall not be designed to be temporary or transitional. Instead, it should a democratic arrangement, which becomes a part of Hong Kong domestic politics (Zheng, 2011, pp. 255-256).

In summary, the chief executive of Hong Kong possess the critical role, including the balance of power of Hong Kong society and coordination between Hong Kong and the central government. Therefore, a chief executive shall be the one with most political support from the Hong Kong society and central government. The Nominating Committee ensures a candidate of such high caliber is selected. It is very important for Hong 
Kong's stability and prosperity that the Nominating Committee can operate with independency, as an important institutional design for elite governance in Hong Kong and a critical mechanism to elect patriotic leadership. In this sense, the Nominating Committee is a formality of elite representativeness, and a type of practice of elite democracy.

\section{The Universal Suffrage of the Chief Executive Reflects the Popular Request}

The chief executive is the pivot of decision-making in Hong Kong SAR, and the essential component of political institution of Hong Kong. The universal suffrage was a solemn promise made by the Basic Law of Hong Kong Article 45 and a consensus and agreement of the Hong Kong society. Confined by "the actual situation in the Hong Kong Special Administrative Region and ... the principle of gradual and orderly progress,” the universal suffrage has not been realized during the elections for the first to the fourth chief executive. On December 19, 2007, the Tenth National People's Congress Standing Committee has passed. Decision of the Standing Committee of the National People's Congress on the Methods for Selecting the Chief Executive and for Forming the Legislative Council of the Hong Kong Special Administrative Region in 2012 at its 31st session. This legislative document stipulated that universal suffrage can be implemented for the election for the fifth chief executive. At the 10th session on August 31, 2014, the Twelfth National People's Congress Standing Committee has ratified Decision of the Standing Committee of the National People's Congress on Issues Relating to the Selection of the Chief Executive of the Hong Kong Special Administrative Region by Universal Suffrage and on the Method for Forming the Legislative Council of the Hong Kong Special Administrative Region in the Year 2016. This piece established four principles for election for the chief executive in Hong Kong. According to the principles, all eligible voters shall have rights to elect the chief executive, which reflects universal suffrage and egalitarian principle, suits the basic needs of mass democracy in a modern society, and becomes a historical milestone in democratization of Hong Kong.

The English term, "universal suffrage”, describes universality and extensiveness, emphasizes the scope of eligible voters, and sets as little eligibility requirements for voters as possible. Universal suffrage has the value of egalitarianism, but it does not equal to "One person, one vote” (Wang, 2014). Chen Duanhong argued that universal suffrage is to integrate polity with freedom of expression of voters, to repossess and reassign power to representative and executive with a cyclical pattern, and to maintain the consistency among representative, executive, and people, in order to avoid any alienation and betrayal of the former to the latter (Chen, 2014). Briefly speaking, universal suffrage does not equal to direct election or "One person, one vote". Yet, it provides as little voting eligibility requirements as possible, integrates the opinions of voters with a cyclical pattern, and ensures that the executive represents voters' interests.

Jean-Jacques Rousseau argued that people's common will becomes the only legality foundation of the authority through universal suffrage (Rousseau, 2015, pp. 120-123). Universal and fair election is the important source of legality of political authority. In Hong Kong, the universal suffrage would become the foundation of validity of the chief executive and the way to realize mass democracy, which will be elaborated in the following five aspects.

First, the universal suffrage of chief executive in Hong Kong reflects mass democracy. Universal suffrage is a fruit of the society of the mass public. The development of mass democracy indicates the deepening of democracy so that the public can equally enjoy political rights and freedom and participate in the state and 
public affairs. The Basic Law of Hong Kong has bestowed the rights to participate in the public affairs to Hong Kong permanent residents. The Basic Law of Hong Kong Article 26 states,

Permanent residents of the Hong Kong Special Administrative Region shall have the right to vote and the right to stand for election in accordance with law.

This article manifests the principle that Hong Kong dwellers shall rule in Hong Kong and implies that Hong Kong permanent residents equally enjoy political rights and freedom. The Basic Law Article 45 and the First Amendment clearly stipulates the detailed procedure of the chief executive election. However, it has been two decades from the election by the Nominating Committee to universal suffrage. In other words, universal suffrage is the way to realize the principle that Hong Kong dwellers shall rule in Hong Kong, to enforce the Basic Law, allowing Hong Kong permanent residents elect their chief executive and participate in public affairs, and to display the mass democracy.

Second, universal suffrage is a historical step forward in democratization in Hong Kong, a significant reform in the political institution of the SAR, and a model for democratic development in Mainland China. Democratic institution was established after the sovereignty of Hong Kong was transferred back to Mainland China. As a British colony, Hong Kong with no democracy in the real sense experienced the governing strategy, using Chinese collaborators to subdue the Chinese. After the sovereignty handover, Hong Kong gradually established the principles that Hong Kong dwellers shall rule in Hong Kong under "One Country, Two Systems" and established the Office of Chief Executive and the Legislative Council. Hong Kong society has experienced constitutionalism reform and made strides in democratic development (Rao, 2014). It is not just important to Hong Kong, but also to China. Only from the perspective of its impact on China can we better understand the significance of universal suffrage.

Third, universal suffrage for the election of chief executive does not equal to direct democracy. At present, the widespread opinion in Hong Kong is that universal suffrage means direct election and "One person, one vote”. Some argue that it is not necessary to go through the Nominating Committee for candidate nomination; some believe that the right procedure of nomination should be nomination by a citizen, then by a party, and later by the Nominating Committee; and others propose that the divide of functional constituency in the Nominating Committee should be terminated and that direct election should be implemented at the Legislative Council. We believe that universal suffrage does not equal to direct election. The universal suffrage means that all residents equally enjoy the rights to vote, which is different from direct election for the chief executive or members of the Legislative Council. The direct democracy means that the power of decision-making lies in all citizens, instead of party as an intermediate. Briefly speaking, universal suffrage, as a horizontal type, means the extensiveness of suffrage that citizens enjoys. Direct democracy, as a vertical type, means that voters participate in public affairs through voting. Universal suffrage emphasizes the rights to vote, different from "One person, one vote”. Direct democracy stresses on the form of decision-making and citizens' participation in public affairs without party as an intermediate.

Fourth, the chief executive election in Hong Kong is a regional election, and it is not an election of a national state. According to the Basic Law Article 12,

The Hong Kong Special Administrative Region shall be a local administrative region of the People's Republic of China, which shall enjoy a high degree of autonomy and come directly under the Central People's Government. 
In other words, Hong Kong is an administrative entity of a unitary state, a special administration region with high degree of autonomy. The suffrage of the chief executive is virtually an election of a regional administrative division, subject to the Basic Law of Hong Kong and relevant decisions of the National People's Congress. So it should not be understood with the definition of universal suffrage at the national level. Yet, it should be a regional democratic election featuring the characteristics of Hong Kong. Therefore, only from the perspective that Hong Kong is a local administrative region with a high degree of autonomy can we understand the political and historical significance of the election of the chief executive of Hong Kong.

Fifth, functional constituency is professional representation in representative democracy. One cannot deny the nature of suffrage with functional constituency. Paul S. Reinsch pointed out that legislative organ shall represent not only regional interests, but also professional associations (Reinsch, 1923). The modern society sees frequency of moving. The stakes of many professionals center on their jobs, but not their residency. An electoral mechanism, dividing constituency based on professional and industry, should better represent pursuits in the society. In other words, the functional constituency in Hong Kong is a form of corporatism. If suffrage is to protect democracy, functional constituency is to balance the power and needs of various social classes and associations. The balanced participation demonstrated by functional constituency is one of the important principles in political development in Hong Kong and is suitable to election of the Chief Executive and the Legislative Council (Li, 2012). The functional constituency is an important part of representative democracy of Hong Kong and should not be used to deny universal suffrage.

In summary, the chief executive is the most powerful political leader in Hong Kong SAR. A universal suffrage to elect its executive reflects the fundamental principles of mass democracy. It is a historical improvement in democratization in Hong Kong, an important milestone in political development of Hong Kong, and a democratic achievement under "One Country, Two Systems” by the Chinese government.

\section{Conclusion and Discussion}

In terms of modern political science, democracy means the democratic election in nation states. Hong Kong's suffrage for the chief executive is a regional election within a unitary country. Lau Siu Kai argued that Hong Kong is a special administrative region of the People's Republic of China, so it doesn't have sovereignty and corresponding power as a nation state. Under “One Country, Two Systems”, Hong Kong is awarded a high degree of autonomy by the central government, yet not full autonomy. Therefore, it is difficult to draw a comparison between Hong Kong's democratization, featuring its own characteristics, and other countries' democratic evolvement. One can only understand and analyze it drawing from Hong Kong's history background and present situation (Lau, 2014, p. 19). Inspired by Lau's argument, we analyze the election of the chief executive of 2017 from the perspectives of elite democracy and mass democracy.

From the angle of political science, modern democratic politics lie in balance of power as well as accountability. In the eye of political philosopher, democracy needs to be understood as a concept of comparison because only with comparison can democracy be grasped as an institution distinguished from others (Thomas, 2006, p. 252). Elite democracy and mass democracy is a pair of concepts, which balance each other. Elite democracy proponents believe that democracy has its limitation and does not equal to governance by the public. Other than voting, the public participation in politics is dangerous and infeasible. They even argue that any polity is legitimate when it satisfies a minimum requirement, which is a voter has a chance to select between two political elite candidates. This theory of elite democracy ignores the inner value of 
democracy and the quality of governance. That is why some scholars, like Wang Shaoguang calls this democracy as selection of candidate. In contrast, ever since the Enlightenment, political thinkers have questioned and criticized the mass public and mass democracy. Meanwhile, it is needed to form consensus on democratic system, cultivate civilized citizens with tolerance and compromise, and make mass democracy possible. Thus, egalitarian pursuit of mass democracy can complement elite democracy due to its lack of legality, and moreover, elite democracy can prevent mass democracy from nationalism and irrationality.

The suffrage of the chief executive of Hong Kong in 2017 reflects the dialectic unity. Having been through the compromise and competition between various stakes and principles, the suffrage of the chief executive is not just a basic requirement of modern democratic society, but also a necessary institutional arrangement to provide social cohesion and ethical elevation. However, the construction of democracy is a long haul that needs persistent efforts. We do not expect that the democratization in Hong Kong will be accomplished through a few times of election for the Chief Executive and the Legislative Council. Instead, it calls for the efforts of Hong Kong people, as well as their compromise, power play and balance, through which it would achieve the democratic political institution featuring local characteristics.

\section{References}

Bryan, C. (2007). The myth of rational voter: Why democracies choose bad policies. Princeton University Press.

Chen, D. H. (February 2014). The legality and democratic justification of the Chief Executive of Hong Kong Special Administrative Region. Journal on Hong Kong and Macau.

Hao, Z. (2006). Dim consciousness and democratic tradition. Beijing: New Star Press.

Heywood, A. (2009). Political theory. Beijing: China People University Press.

Huntington, S. (1998). The third wave: Democratization in the late Twentieth Century. Shanghai: Joint Publishing.

Lau, S. K. (2014). The unique democratic path of Hong Kong. Hong Kong: The Commercial Press.

Li, X. H. (May 2012). The legal basis and feasibility study of functional constituency in suffrage of Hong Kong. CASS Journal of Political Science.

Miller, D. (Ed.). (2002). The blackwell Encyclopedia of political thought. Beijing: China Political Science and Law University Press.

Reinsch, P. S. (1923). The Fundamental Principles of Government. Changchun, Jilin Publishing Group.

Rao, G. P. (March 2014). The necessary road to the universal suffrage of the Chief Executive of Hong Kong. Journal on Hong Kong and Macau.

Rousseau, J. J. (2003). The social contract. Beijing: The Commercial Press.

Schumpeter, J. (1999). Capitalism socialism, and democracy. Beijing: The Commercial Press.

Shi, G. Q. (2014). Competition behind Hong Kong Chief Executive nominating mechanism: The politics and legal theory. Economic Tribunal, August.

Stromberg, R. (2005). An intellectual history of Modern Europe. Beijing: Central Compilation and Translation Press.

Tocqueville, A. D. (1997). Democracy in America. Beijing: The Commercial Press.

Thomas, G. (2006). An introduction to political philosophy. Beijing: China People’s University Press.

Wang, S. G. (2008). The four talks of democracy. Beijing: Joint Publishing.

Wei, G. G. (2008). Mass democracy: Literal interpretation and logic reconstruction of a thought. Wuhan: The Wuhan University Press.

Wang, L. (2014). The relationship between Universal suffrage and direct election. Journal on Hong Kong and Macau, January.

Yu, K. P. (January 5, 2007). Democracy is a good thing. Xuexi Times.

Zheng, Y. N. (2011). Zhongguo GuojiMingyun. Hangzhou: Zhejiang Chuban United Group. 